(2020) 26 JUUM $43-50$

https://doi.org./10.17576/juum-2020-26-05

\title{
The Law and Challenges to Access Medical Record for Medical Negligence Claims in Malaysia
}

\author{
Maizatul FARISAH MoHD MoKhtar
}

\begin{abstract}
Medical records are one of the most essential documents for a plaintiff in medical negligence claims if the plaintiff is the patient. Medical records are used for 'discovery' in preliminary proceeding to establish the case which is the cause of action as well as to show negligence and causation during the trial. Medical records provide important information to determine whether a medical practitioner was negligent or not. But patients have no authority to access and keep medical records. The parties who have the authority to keep and access medical records are the medical practitioners (who provide the medical records) and the hospital or clinic, or any other healthcare institute. They have the legal obligation to protect and keep the confidentiality of the medical records. Therefore, plaintiffs must first obtain a court order prior to obtaining their medical record. However, the decision made in the case of Nurul Husna Muhammad Hafiz \& Anor v Kerajaan Malaysia \& Ors [2015] 1 CLJ 825 has changed the law pertaining to the obtaining a court order for access to medical records. This paper considers medical records for medical negligence claims in court as well as the law governing medical records and the challenges and obstacles faced in obtaining medical records from the perspective of the law on confidentiality. Finally, it also discusses the decision made in the case of Nurul Husna Muhammad Hafiz \& Anor v Kerajaan Malaysia \& Ors [2015] 1 CLJ 825 which according to the court parties who wish to access medical records for medical negligence claims no longer require an order of a court to do so.
\end{abstract}

Keywords: medical record; medical negligence claim; discovery; confidentiality; Malaysia

\section{INTRODUCTION}

Medical records are a document related to medical details relating to the health of a patient, such as the patient's medical history, and any treatment received. These details are recorded by medical practitioners. The definition of a medical record according to the Malaysian Medical Counsel (MMC) Guidelines on Confidentiality, which was revised on 11 October 2011 from The Guideline of The Malaysian Medical Counsel [MMC GUIDELINE 002/2006] Medical Records and Medical Reports:

\footnotetext{
"A medical record is documented information about the health of an identifiable individual recorded by a practitioner or other healthcare professional, either personally or at his or her instructions. It should contain sufficient information to identify the patient, support the diagnosis based on history, physical examination and investigations, justify the professional management given, record the course and results thereof, and ensure the continuity of care provided by practitioners and other healthcare workers to that particular patient."
}

Patient's medical records contain medical history, diagnosis, treatment, details provided by the patient himself/herself, patient's character and attitude, family details, events affecting the patient. They are recorded by medical practitioners including his/her medical personal notes regarding the patient. ${ }^{1}$ Although this document contains all the information related to the patients, it is confidential, and patient has no right to keep the medical record. Who then, keeps and has access to the medical records? A doctor's duty of confidentiality goes beyond undertaking not to divulge confidential information-it includes the responsibility of ensuring that written patient information is kept securely. ${ }^{2}$ Besides, the doctor, the hospital, clinic or any healthcare institute, who is the authorised person or body who has the obligation to keep and has right of access to the medical record.

Relating to medical negligence claims, why is the medical record essential for a plaintiff, for instance a patient, who wants to take legal action in court? For a medical negligence claim to succeed using litigation, a medical record is a compelling document that contains all the medical information and treatment including doctor's notes which are essential to link the negligence and the damages such as injury suffered by the plaintiff. Therefore, a patient's medical record is the most important tool to determine if he or she has a strong case or not before pursuing a legal suit for medical negligence. ${ }^{3}$ 
In other words, it is essential for a plaintiff to have the medical record in order to establish a medical negligence claim in court. However as mentioned earlier, although the medical record is the vital documents for a plaintiff in medical negligence case against for instance, a doctor and hospital, he or she has no right and is unable to access the medical record unless permitted by the law. It is not easy for a plaintiff to obtain the medical records from the party whom the claim is against.

\section{MEDICAL RECORDS IN MEDICAL NEGLIGENCE CLAIM}

Generally, in court, medical records are used to prove criminal cases in regard to the nature, timing, and severity of the injuries or death and are considered as important evidence. ${ }^{4}$ Beside criminal cases, medical records are also important in other cases such as road traffic accident cases and accident cases in workplace. In addition, medical records are also essential for insurance claims or example claims for indemnity for illness and death. For medical negligence, medical records are not only essential for claims but also in a criminal action for criminal negligence.

As mentioned earlier, medical records are the most essential tool for a plaintiff to bring a medical negligence claim before a judge. Why are medical records crucial for medical negligence claims? One of the main reasons medical records are compelling for medical negligence cases and a claim is to establish causation (causal link). The first step for any civil legal action is to determine a reasonable cause of action, which generally can be understood as the grounds to file a legal suit. Filing any legal action requires justifying the legal action taken. For instance, in a medical negligence claim, the plaintiff's lawyers must classify the grounds of claim based on the provision of sufficient facts in the case and this may include evidence of a medical expert in a medical report. But what exactly is 'a cause of action', and how does it operate in medical negligence cases? In regard to medical negligence cases under procedural law, 'a cause of action' can be defined as 'the ground on which an action can be maintained; as when we say that such a person has no cause of action or sometime can also be referred to as a person having a right of action'. Furthermore, after establishing the cause of action whereby it is shown that there are damages in medical negligence cases, it is also important to prove the causation. For instance, whether the damages suffered by the patients or plaintiff are connected to or linked to the doctor's actions. To prove this causation, a medical record is essential and gives the history of treatment and diagnosis made by the doctor to prove that the doctor's actions has connection or link to the damages suffered by the patient.

The implication of the establishment of cause of action is that the involved party, including any third party such as parents, wife, or husband of the party who suffered damages from the negligence, has the right and is entitled to compensation under Section 7 of Civil Act 1956 (Act 67):

"Compensation to the family of a person for loss occasioned by his death:

7. (1) Whenever the death of a person is caused by wrongful act, neglect or default, and the act, neglect or default is such as would, if death had not ensued, have entitled the party injured to maintain an action and recover damages in respect thereof, the party who would have been liable if death had not ensued shall be liable to an action for damages, notwithstanding the death of the person injured, and although the death has been caused under such circumstances as amount in law to an offence under the Penal Code [Act 574]."

Beside establishing the cause of action in preliminary proceedings and causation in trial, the purpose of medical records being used as evidence is to counter the claim or rebut the evidence during cross examination. For instance, in a medical negligence claim trial, the plaintiff's provision of a statement and evidence that patients suffered damages which is an injury due to medical negligence can be rebutted during the cross-examination with arguments as to what extent the evidence is true; accordingly, the doctor's claim that the action taken was according to the standard duty of care, can be rebutted in cross-examination. Cross-examination in the litigation process affords the essential values of finding the truth and securing justice.

\section{THE LAW AND CHALLENGES TO ACCESS MEDICAL RECORDS DUE TO CONFIDENTIALITY}

Based on the discussion above, it is very important for a plaintiff to obtain and have access to medical records in establishing his or her case in court in medical negligence claims. However, there are challenges in obtaining and accessing medical records. These include the law governing medical 
records and whether medical records have been kept properly by the authorised person or body especially in government hospitals. These contribute to the difficulties in getting access to the records.

The legal provision that relates to medical records falls under Personal Data Protection Act 2010 (Act 709). However, to what extent this Act can be used to obtain and access medical records? According to Personal Data Protection Act 2010 section 8:

Section 8: Subject to section 39, no personal data shall, without the consent of the data subject, be disclosed -

a. for any purpose other than -

i. the purpose for which the personal data was to be disclosed at the time of collection of the personal data; or

ii. a purpose directly related to the purpose referred to in subparagraph (i);or (b)to any party other than a third party of the class of third parties specified in paragraph 7(1)(e).

Meanwhile in Section 39 provides the exceptions to the general prohibitory rule in section 8 and they are essentially:

i. where consent for disclosure is given.

ii. where disclosure is necessary to prevent or detect crime or for the purposes of investigations. (iii) where disclosure is required or authorised by or under any law or by the order of a court.

iii. where there is reasonable belief that there is a legal right to disclose the data.

iv. reasonable belief that consent would have been given if the giving of the date and the circumstances of disclosure is known.

v. public interest as determined by the minister.

Based on the provision above, there are circumstances whereby the disclosure of medical records can be made which falls under section 8. However, under section 39 of the Act there are limitations for the circumstances of disclosure. Therefore, the question is who owns and keeps the medical records? The next question is who has access to medical records, although section 39 provides the circumstances to allow for such disclosure, does this provision allow parties involved in medical negligence claims to do so?

According to The Guideline of The Malaysian Medical Counsel [MMC GUIDELINE 002/2006] 'A patient's medical record is the property of the medical practitioner and the healthcare facility and services, who hold all rights associated with ownership'. Furthermore, Regulation 44 (1) of the Private Healthcare Facilities and Services) Regulations 2006 states that 'A patient's medical record is the property of a private healthcare facility or service'. Therefore, based on the Guideline and provision above, patients have no right to keep and access their medical record as it must be kept confidential by the authorised person or body such as doctor, hospital, or healthcare institute.

If any authorised person or body holdings the medical records would like to disclose the medical report to any third party, they need to obtain consent from the patients prior to the disclosure. ${ }^{5}$ However, personal information about the patients such as name, address, identification data, etc. belong to patients as well as the test results such as blood tests, tests on secretions, imaging and scans and must be released upon request from patients. ${ }^{6}$ Besides that, for information obtained by the third party (relatives mainly) about patients such information may have been revealed by the hospital medical practitioners on strict instructions. Medical practitioners may reveal the information in providing the Medical report for patients but limited only to information only not the sources. ${ }^{8}$

Therefore, records are accessible only by the authorised person, and even patients have no access to them. A doctor's duty of confidentiality goes beyond undertaking not to divulge confidential information-it includes the responsibility of ensuring that written patient information is kept securely. ${ }^{9}$ According to the International Code of Medical Ethics: ${ }^{10}$

"A doctor shall preserve absolute secrecy on all he knows about his Patients because of the confidence entrusted in him."

In addition, according to the Declaration of Geneva, a doctor:

\footnotetext{
"Respects the secrets that have been confided in me even after patient has died."
} 
Medical records are also a confidential document whereby they can only be accessed by authorised person or body. Why are medical records confidential? One of the reasons medical records are confidential is to respect patients' individual rights and privacy. For example, for any medical treatment of a disease, a patient might specifically not want to be disclosed to others. For example, if a patient suffers from HIV and takes medicine known as HAART ${ }^{11}$ to control the amount of virus known as CD4 in the blood to prevent AIDS. HIV is considered a sensitive health condition and can create a stigma ${ }^{12}$ therefore is it important for such medical information to be confidential. Furthermore, it is part of a doctor's obligation towards patients to ensure that the medical records are kept confidential. This is also necessary to gain trust and confidence and also to preserve the good relationship between doctor, hospital or healthcare institute and patients. In addition, the importance of medical record confidentiality is for the doctor-patient relationship especially to encourage patients to disclose all material information including that which is considered private. All of this information will be confidential and protected under the privilege of the doctor-patient relationship. Therefore, patients should not worry about the possibility that private information will be exposed or disclosed to other parties.

In Malaysia, the obligation to preserve the confidentiality of medical records is laid down in the Malaysian Medical Counsel Guidelines on Confidentiality, which was revised on 11 October 2011 from The Guidelines of The Malaysian Medical Counsel [MMC GUIDELINE 002/2006] Medical Records and Medical Reports:

"The justification for this information being kept confidential is that it enhances the patient-doctor relationship. Without assurances about confidentiality patients may be reluctant to give doctors the information they need in order to provide good care."

However, there are exceptions to medical confidentially whereby records can be disclosed by the practitioners, according to the Malaysian Medical Counsel (MMC) in the revised guideline:

3. Confidentiality is an important duty, but it is not absolute. A practitioner can disclose personal information if:

a. it is required by law (paragraphs 15-20);

b. the patient consents - either implicitly for the sake of their own care or expressly for other purposes; or c. it is justified in the public interest (paragraphs 34-48).

Therefore, based on these circumstances, any confidential records will remain confidential, except where the record must be disclosed in court as part of the evidence. However, the disclosure is limited only to the extent the court requires disclosure. Hence, the plaintiff or claimant may never see the full records or any part of the nondisclosed record.

\section{OBTAINING MEDICAL RECORDS BY WAY OF COURT ORDER}

Based on the discussion above, patients or their next of kin have no rights regarding the ownership and access to medical records but medical records are essential material for medical negligence claims. Therefore, how do patients or plaintiff establish a claim in court? Common law generally allows patients the right to access medical records though this is not an absolute right. ${ }^{13}$ According to the English Court of Appeal in Regina $v$ Mid Glamorgan Family Health Services Authority and Another,${ }^{14}$ Lord Judge Evans held that:

"In my judgment, there is no good reason for doubting either that a right of access does exist or that it is qualified to that extent at least. The record is made for two purposes which are relevant here: first, to provide part of the medical history of the patient, for the benefit of the same doctor or his successors in the future; and, secondly, to provide a record of diagnosis and treatment in case of future inquiry or dispute. Those purposes would be frustrated if there was no duty to disclose the records to medical advisers or to the patient himself, or his legal advisers, if they were required in connection with a later claim. Nor can the duty to disclose for medical purposes be limited, in my judgment, to future medical advisers. There could well be a case where the patient called for them in order to be able to give them to a future doctor as yet unidentified, eg. in case of accident whilst travelling abroad."

Furthermore, according to The Guideline of Malaysian Medical Counsel [MMC GUIDELINE 002/2006] under Malaysian Medical Counsel (MMC), the principle governing access to medical record is:

\subsection{Access to Medical Records}

The patient may be entitled to access medical records as part of the contract between him/her and the medical practitioner, for various purposes, ranging from need to seek second opinion, to seek further treatment elsewhere, or for litigation. This privilege is also extended with the patient's consent to the patient's appointed agents. 
Normally, medical practitioners and persons in charge of healthcare facilities and services should not object to the release of results and reports of the patient's laboratory investigations, X-rays and scans, and other such diagnostic tools, which the patient would have paid for personally or through insurance.

Medical practitioners and persons in charge of healthcare facilities and services are generally expected to cooperate and release all parts of the medical records, or certified true copies of the records, when so requested by the patient.

If the patient's or agents' request for access is refused after all other avenues have been explored, a patient may then resort to civil action. Legal proceedings are commenced by issuing a writ to permit the process of 'order of discovery' to proceed after which documents may be subpoenaed.

When medical records are taken out from the private healthcare facility or service whether by a court order, or mutual consent, a copy of the records shall be retained by the private healthcare facility or service and the original records shall be returned to the private healthcare facility or service at the end of the proceedings for which the records were directed to be procured.

The patient, and/or his appointed agent/officer, on written request, is entitled to a written report on the care given to the patient as recorded in the medical record, and relevant copies of their medical records. The healthcare facility is not liable for any interpretation or analysis of the medical record made by a third party.

The withholding of information of the care, diagnosis, treatment and advice given to the patient, and relevant copies of the medical records, is unethical.

The other law regulates the access to medical records and obtaining them via a court order contained in Regulation 44 of the Private Healthcare Facilities and Services (Private Hospitals and Other Private Healthcare Facilities) Regulations 2006 (“PHFSA (Reg) 2006”)

"No patient's medical record shall be taken out from the private healthcare facilities... except under a court order".

Thus, in the Malaysian court, for medical negligence claims, for the plaintiff to access medical records during the preliminary proceedings to proceed with litigation, he/she needs to obtain a court order by application; once this is received, the plaintiff can issue the court order to the doctor or hospital and obtain the medical report. ${ }^{15}$ The court has the discretion to grant this order under Order 24 if the discovery is deemed necessary:
"Order for discovery (O. 24, r. 3) 3. (1) Subject to the provisions of this rule and of rules 4 and 8 , the Court may at any time order any party to a cause or matter (whether begun by writ, originating summons or otherwise) to give discovery by making and serving on any other party a list of the documents which are or have been in his possession, custody or power and may at the same time or subsequently also order him to make and file an affidavit verifying such a list and to serve a copy thereof on the other party."

Yekambaran Marimuthu v Malayawata Steel Berhad $^{16}$ articulates the most essential elements of 'discovery' regarding access to medical records:

1. The essential elements for an order for discovery are three fold, namely first, there must be a "document", secondly, the document must be "relevant" and thirdly, the document must be or have been in the "possession, custody or power" of the person against whom the order for discovery is sought. It is indisputable that the items sought were documents and were in the possession, custody or power of the defendant.

2. As to "relevance", the Rules of the High Court limit discovery to documents which are "relevant to" or relate to the factual issues in dispute. In practice, relevance is primarily determined by reference to the pleadings but there need not be pleadings for a matter to be in issue.

4. It was incumbent for the plaintiff to set out the wrong he believes he has suffered, the reason why he believes this to be so and why it is necessary that the defendant be ordered to give discovery.

Hence, from the above principle laid down in the case, the essential elements of 'discovery' for access medical to records according to the law are firstly; there must be documents, secondly it must be a document relevant to the facts of case and finally it must be in the possession or custody of an authorised person that resulted in patients being unable to get the access to the documents. In addition, it is important to issue and justify the importance of accessing records that relate specifically to actual damages.

There is also a provision for accessing medical records under the Malaysian Criminal Procedure Court (CPC) (Act 593), although medical negligence claims for the purpose of this fall under civil cases. The function of the CPC relating to medical negligence in the legal context pertains to post-mortem procedures. Any person who is aware of the sudden death, unnatural death, death by violence, death under suspicious circumstances, or death with unknown cause must immediately give the information to an officer at the nearest police station or to the village head under the Section 13 (10) (b) of the CPC (Act 593): ${ }^{17}$ 
b. of any sudden or unnatural death or death by violence or of any death under suspicious circumstances, or of the body of any person being found dead without its being known how that person came by death;

shall in the absence of reasonable excuse, the burden of proving which shall lie upon the person so aware, immediately give information to the officer in charge of the nearest police station or to a police officer or the nearest penghulu ${ }^{18}$ of the commission or intention or of the sudden, unnatural or violent death or of the finding of the dead body, as the case may be.

A post-mortem conducted by the coroner is necessary if there is an inquest to conduct one, an inquest being the preliminary inquiry for obtaining certain facts regarding the death in question. ${ }^{19}$ There are several circumstances in which an inquest is involved in the context of medical negligence relating to post-mortem such as deaths following anaesthesia, surgery or any medical investigative procedure, death in mental institutions, asylums etc., and deaths associated with pregnancy, abortion, childbirth etc. ${ }^{20}$

A post-mortem is necessary when the investigating officer suspects that the deceased's death was sudden or unnatural. The body is sent to the nearest government hospital or any other convenient place to be examined by the medical officer (pathologist), who conducts the post-mortem not only to confirm the cause of death but also for the following purposes: $:^{21}$

1. Identifying the deceased;

2. Documenting the injuries, their description, nature and distribution;

3. Ascertaining whether the injuries and their distribution are consistent with a given history;

4. Reconstructing the event of death when a proper eye witness account or a history is not available;

5. Deciding whether to accept or refute an eye witness account;

6. Discovering any other underlying cause or disease that has contributed to the death;

7. Ascertaining the possibility of any voluntary act that the deceased may have performed after sustaining the injury;

8. Ascertaining whether the injuries found were inflicted before or after death;

9. Collecting trace materials on the victim which may help to solve a crime such as tracing a hit and run vehicle, arresting a rapist murderer etc.

\section{THE IMPLICATION OF JUDGMENT IN THE CASE OF NURUL HUSNA MUHAMMAD HAFIZ \& ANOR V. KERAJAAN MALAYSIA \& ORS}

As discussed previously, the implication of the confidentiality of medical records is restricted.
Patients or plaintiffs who want to obtain and access to them need to get a court order. In order to get the court order, a plaintiff must justify and prove the necessity of access to the medical records. If, after taking into the consideration the relevancy and the importance of the medical records to the plaintiff, the court considers access is necessary, it will grant the court order. However, the law governing the access and discovery of medical records in Malaysia for medical negligence claims has progressed and developed. This development of the new law for 'discovery' can be found in the case of Nurul Husna Muhammad Hafiz \& Anor $v$ Kerajaan Malaysia $\&$ Ors. ${ }^{22}$ This case became the precedent that rebutted previous law. The court in this case decided that parties who wish to obtain and access medical records are not required to get a court order. The Judge Vazeer Alam Mydin Meera in this case highlighted that:

"The prevalent common practice among medical professionals and hospitals is to refuse to give copies of patient's medical records unless ordered by the court to do so. This has necessitated the filing of applications by patients seeking court's intervention to order production of the medical records. In most cases, when the application comes for hearing, the respondent throws in the towel and agrees to produce copies of the medical records sought. In a handful of cases, there is resistance and the court determines the issue to order production. This guarded conduct of the medical professionals and hospitals has caused patients to incur avoidable costs and delays by filing originating processes for an order for discovery of their medical records."

Furthermore, Judge Vazeer Alam Mydin Meera raised the criticism that requiring patients to go through the legal process to obtain medical records exposed patients to the inefficiency of the legal process (burdened with time-consuming and overly complex procedures) at the beginning of the preliminary processing. $\mathrm{He}$ critiques these procedures and established a new principle governing this legal matter:

"Based on the legal duties and rights that arise from the physician-patient fiducial relationship, and further having regard to the provisions in the guideline and the common law principles, the legal position in Malaysia vis-à-vis the patient's right of access to medical records can be summarised as follows:

a. The ownership of a patient's medical record vests with the physician or hospital as the case may be. However, the physician or hospital must deal with the medical records in the best interest of the patient;

b. The patient has an innominate and qualified right of access to his medical records and there is a 
corresponding general duty on the part of the physician or hospital to disclose the patient's medical records to the patient, his agents, medical advisers or legal advisers;"

The previous law's stipulation that the plaintiff must first obtain a court order to access medical records was based on the principle of 'discovery' established under Order 24 Rules of High Court 2012. However, Judge Vazeer Alam Mydin Meera's decision establishes an important principle that has become precedent for the future matter of 'discovery'-namely that is possible to access medical records without first obtaining a court order to do so. Hence, the plaintiff may access records directly from the doctor/hospital.

On the other hand, in this situation, does the doctor have the right to refuse disclosure of medical records? According to Judge Vazeer Alam Mydin Meera:

"The physician or hospital may refuse to disclose partly or
wholly the medical records to the patient in certain limited
circumstances, such as, but not limited to, situations when such
disclosure would be detrimental or prejudicial to the patient's
health in that the information is likely to cause serious harm
to the physical or mental health of the patient or of any other
individual contained in the medical records; or when such
disclosure would divulge information relating to or provided by
an individual, other than the patient, who could be identified
from that information."

The hospital or doctor reserves the right to refuse disclosure of medical records if such disclosure would harm the patient's psychological well-being or possibly cause even greater damages. Therefore, in medical negligence cases, patients may request access to medical records to establish cause of action during preliminary proceedings - provided the disclosure does not pose harmful implications as stated in the above judgement. If it does not, the doctor or hospital must provide access.

However, the argument that arises is to what extent is the principle in this case practically applicable? Do hospitals and doctors in fact provide access to medical records if patients do not possess a court order? It is argued that the implication of the principle in this case is that doctors/hospitals are reluctant to accept medical record requests. As mentioned previously, the plaintiff needs to possess medical records to establish the case against the defendant; having them would afford advantages and strength to the plaintiff's provision of sufficient evidence before the court. Releasing records might be disadvantageous to the defendant's case, so if defendant has the right to refuse access to them, he/she would take that option. Consequently, the plaintiff would ultimately have to go through the procedure in court (under Rules of Court 2012 in Order 24) to get an order to access the records.

\section{CONCLUSION}

Based on the discussion above, although medical records are essential material for medical negligence claims, not only during the trial, but also prior to the trial in preliminary proceeding in litigation process to determine the cause of action and establish if there is a case of negligence and causation and that damage was suffered by the patient. However, due to the unavailability of legislation to allow access to medical records, this makes it a difficult for a plaintiff to access their medical records. The challenges of access to medical records is also because of the ownership and confidentiality of medical records being limited only to authorised persons or bodies such as medical practitioners or hospitals where these authorised parties are those that plaintiff is normally against in a medical negligence claim. This makes the process much more difficult. However, the decision in the case of Nurul Husna Muhammad Hafiz \& Anor $v$ Kerajaan Malaysia $\&$ Ors by the Judge Vazeer Alam Mydin Meera decided that patients who want to access their medical records for discovery do not require to get the court order after taking into consideration the difficulties of the process in obtaining court order.

But the implication of no court order being required to access medical records is that the authorised person or body is aware that there is no legal obligation via court order for them to give the medical record therefore they will be reluctant to give access to medical records that may be used against them. Hence, the patients may still need to go to court and apply for a court order. Eventually, the challenges to obtain medical records may cause the plaintiff, normally the patient who suffers the damages, to be reluctant to proceed with legal action so as to avoid going through the hazardous legal process that is burdening and time-consuming and overly complex at the beginning of the process. Perhaps it is justified for the current law(s) that governs access to medical record such Personal Data Protection Act 2010 (Act 709) to be revised and amended accordingly to give rights of patients to access their medical records particularly in cases of medical negligence. 


\section{NOTES}

1 The contents of a Patient's Medical Record according to The Guideline of The Malaysian Medical Counsel [MMC GUIDELINE 002/2006]

The following intellectual and physical items may, in whole or in part, make up the contents of a patient's Medical Record:

- Doctor's clinical notes

- Recording of Discussion with patient /next of kin regards disease/ management (with witness) / Possible use of tape recording for such discussions

- Referral Notes to other specialist(s) for consultation/ management

- Laboratory \& Histopathological reports

- Imaging records and reports

- Clinical Photographs

- Drug Prescriptions

- Nurses' Reports

- Consent Forms, At-Own-Risk Discharge Forms

- Operation Notes/Anesthetic Notes

- Video Recordings

- Printouts from monitoring equipment

(e.g. Electro-cardiogram, Electro-encephalogram)

- Letters to and from other health professionals

- Computerized/electronic records

- Recordings of telephone consultations/ instructions relevant to the care of the patient.

2 Puteri Nemie Jahn Kassim, Law and Ethics Relating to Medical Profession. International Law Book Services) 2010, 172

3 Puteri Nemie Jahn Kassim, Medical Negligence Law in Malaysia, International Law Book Services, 2008, p.137

4 Thomas J. Medical records and issues in negligence. (2009). Indian journal of urology : IJU : journal of the Urological Society of India, 25(3), 384-388. doi:10.4103/09701591.56208

5 Section 39 of Data Protection Act 2010 (Act 709)

6 The Guideline of The Malaysian Medical Counsel [MMC GUIDELINE 002/2006]

Ibid.

Ibid.

9 Puteri Nemie Jahn Kassim, Law and Ethics Relating to Medical Profession (1st Published 2007, Reprinted 2010, International Law Book Services) 172

10 Ibid

11 According to National Institute on Drug Abuse, HAART is: 'HAART is a customized combination of different classes of medications that a physician prescribes based on such factors as the patient's viral load (how much virus is in the blood), the particular strain of the virus, the CD4+ cell count, and other considerations (e.g., disease symptoms). Because HAART cannot rid the body of HIV, it must be taken every day for life. HAART can control viral load, delaying or preventing the onset of symptoms or progression to AIDS, thereby prolonging survival in people infected with HIV. HAART has been in use since 1996 and has changed what was once a fatal diagnosis into a chronically managed disease.'
'HIV/AIDS: What Is HAART?' (National Institute on Drug Abuse)

12 Muhammad Ajib bin Abd Razak and Nasrudin Subhi, 'Different Levels of HIV/Aids Knowledge and Stigma of GMI and UKM Students Based on Levels of Education' (2016) 30 (1) Malaysian Journal of Psychology, p. 61-68

13 Judge Vazeer Alam Mydin Meera in the case of Nurul Husna Muhammad Hafiz \& Anor V. Kerajaan Malaysia \& Ors [2015] 1 CLJ 825

14 [1995] 1 WLR 110

15 Nurul Husna Muhammad Hafiz \& Anor V. Kerajaan Malaysia \& Ors [2015] 1 CLJ 825

16 [1994] 2 CLJ 581

17 Abdul Rani Kamarudin, 'Inquiry of deaths under the Malaysian Criminal Procedure Code' [2009] 5 MLJ 1xviii

18 "Penghulu" means leader of community people for instance in the village.

19 Kasinathan Nadesan, 'The importance of the Medico-legal Autopsy’ (1997) 19 (2) Malaysian J Pathol.

20 Ibid.

21 Ibid.

22 [2015] 1 CLJ 825

\section{REFERENCES}

Abdul Rani Kamarudin. 2009. Inquiry of deaths under the Malaysian Criminal Procedure Code. 5 MLJ 1xviii

Kasinathan Nadesan. 1997. The importance of the medico-legal autopsy. Malaysian J Pathol.19 (2)

Muhammad Ajib Abd Razak \& Nasrudin Subhi. 2016. Different levels of HIV/Aids knowledge and stigma of GMI and UKM students based on levels of education. Malaysian Journal of Psychology 30 (1): 61-68

Nurul Husna Muhammad Hafiz \& Anor V. Kerajaan Malaysia \& Ors [2015] 1 CLJ 825

Private Healthcare Facilities and Services (Private Hospitals and Other Private Healthcare Facilities) Regulations 2006 ("PHFSA (Reg) 2006")

Puteri Nemie Jahn Kassim. 2010. Law and Ethics Relating to Medical Profession. International Law Book Services

Puteri Nemie Jahn Kassim. 2007. Medical Negligence Law in Malaysia. International Law Book Services

Regina v Mid Glamorgan Family Health Services Authority and Another [1995] 1 WLR 110

The Guideline of The Malaysian Medical Counsel [MMC GUIDELINE 002/2006]

Thomas J. 2009. Medical records and issues in Negligence. Indian Journal of Urology: Journal of the Urological Society of India 25(3), 384-388

Yekambaran Marimuthu v Malayawata Steel Berhad [1994] 2 CLJ 581

Maizatul Farisah Mohd Mokhtar

Islamic Science University of Malaysia

71800 Nilai, Negeri Sembilan, Malaysia

Email: maizatulfarisah@usim.edu.my 